\title{
An Empirical Investigation on Trade Openness and Economic Growth in Bangladesh Economy
}

\author{
Umme Humayara Manni $^{1}$, Shamim Ahmad Siddiqui ${ }^{2}$ \& Munshi Naser Ibne Afzal ${ }^{1}$ \\ ${ }^{1}$ Faculty of Business, Economics and Policy Studies, Universiti Brunei Darussalam, Brunei \\ ${ }^{2}$ E-School of Business \& Quality Management, Hamdan Bin Mohammed e-University, Dubai, UAE \\ Correspondance: Munshi Naser Ibne Afzal, Faculty of Business, Economics and Policy Studies, Universiti \\ Brunei Darussalam, Jalan Tungku Link, BE-1410, Brunei. Tel: 673-714-6601. E-mail: munshi.naser@gmail.com
}

Received: May 16, 2012 Accepted: June 9, 2012 Online Published: August 17, 2012

doi:10.5539/ass.v8n11p154

URL: http://dx.doi.org/10.5539/ass.v8n11p154

\begin{abstract}
The objective of this paper is to assess the impact of trade liberalization on Bangladesh economy between the periods 1980 to 2010. This research analyzes the achievements of the economy in terms of important variables such as growth, inflation, export and import after trade liberalization. The paper uses simple Ordinary Least Square (OLS) technique as methodology for empirical findings. The analysis clearly indicates that GDP growth increased consequent to liberalization. Trade liberalization does not seem to have affected inflation in the economy. The quantitative analysis also suggests that greater openness has had a favourable effect on economic development. Both real export and imports have increased with greater openness. Liberalization policy certainly improves export of the country which eventually leads higher economic growth after 1990s. The findings of this study can be an interesting example for trade liberalization policy study in developing countries.
\end{abstract}

Keywords: trade liberalization, economic growth, developing countries, Bangladesh economy, OLS technique, trade openness, export, import, inflation

\section{Introduction}

Like many developing countries, the primary focus of policies in Bangladesh is to obtain high and sustainable growth. However, to achieve and maintain a higher growth rate, policy makers need to understand the determinants of growth as well as how policies affect growth. Trade liberalization policy in 1990 opened up the opportunity for the Bangladesh economy to enhance economic growth and foster overall development. Trade openness can have a positive effect on economic growth, exports, imports, FDI and remittance of a country. The history of Bangladesh's economy starts in the 1960s, where the then East Pakistan's economy grew by an annual average rate of around 4 per cent. About a fifth of that economy was destroyed during the Liberation War of 1971, and severe dislocations caused at that time left Bangladesh on a slower economic growth trajectory for the following two decades. Then the economy accelerated sharply from 1990 due to mainly trade openness and restoration of democracy (Islam, 2001). In the last two decades Bangladesh economy was characterized by successful expansion of export-oriented garment industry, high-yield variety rice production, leather products, tea and remittances. These enabled Bangladesh to survive the decline of the world market for its former stable exports of jute and jute textiles, and to redeploy its resources in line with its comparative advantage. Many researchers point out this phenomenon as a positive contribution of liberal trade policy (Ahmed and Sattar, 2004). This study uses OLS technique to find out the impact of trade openness on export, import, inflation and overall economic growth during the period of 1980 to 2010. This study breaks down the objective of finding out the impact of trade liberalization on economic growth of Bangladesh into four main sections. Starting with introduction, literature review in section 2 where it highlights some work on trade liberalization and economic growth of developing countries, section 3 is the methodology, section 4 discuss the results and findings and subsequently section 5 draws the conclusion.

\section{Literature Review of Trade Liberalization in Developing Countries}

Most of the economic literature considers that trade liberalization leads to an increase in welfare derived from an improved allocation of domestic resources. Import restrictions of any kind create an anti-export bias by raising the price of importable goods relative to exportable goods. The removal of this bias through trade liberalization 
will encourage a shift of resources from the production of import substitutes to the production of export-oriented goods. This, in turn, will generate growth in the short to medium term as the country adjusts to a new allocation of resources more in keeping with its comparative advantage (McCulloch, Winters and Cirera, 2001). The most compelling argument for greater liberalization comes from the effects on economic efficiency, which promotes private investment and economic growth. Higher growth in turn helps lower poverty by increasing employment and real incomes of the poor. In an influential paper, Krugman (1990) summarized the reasons why trade liberalization is good for growth in developing countries. Firstly, Developing countries have production patterns that are skewed towards labor-intensive service, agriculture and manufacturing. People have low per capita incomes and markets in such countries are usually small. A liberalized trade regime allows low-cost producers to expand their output well beyond that demanded in the domestic market. Secondly, whereas industrialization based on protection of domestic industries thus results in even-higher capital intensity of production, the open trade regime permits enjoyment of constant returns to scale over a much wider range and finally import substitution regimes normally give bureaucrats considerable discretion either in determining which industries should be encouraged or in allocating scarce foreign exchange in a regime of quantitative restrictions, leading to serious efficiency losses. On the other hand, open trade regimes force greater reliance on the market. Empirical evidence on the positive effects of liberalization on growth is quite abundant (Dollar, 1992; Frankel and Romer, 1999; Dollar and Kaaray, 2001; Bhagwati and Srinivasan, 2001; Wacziarg, 1998). However, there are some critics who dispute these findings on methodological ground (Rodrik, 1996; Rodriguez and Rodrik, 1999). Rodriguez and Rodrik caution that their main intention is to challenge the over-enthusiasm on the questionable outcomes of many researches showing strong positive correlation between openness and growth rather than to convey the message of trade protection is good for growth. The most well-known recent study that provides evidence on trade liberalization, growth and poverty reduction is that of Kraay and David Dollar (2001). The study concludes that one third of the developing countries of the world, described as rapid globalizers, did extremely well in terms of income growth and poverty reduction over the past two decades or so. These countries, which include Bangladesh, India and Sri Lanka in South Asia, have experienced large increases in trade and significant reduction in tariff and non-tariff barriers. Bangladesh, for instance, saw its trade GDP ratio almost double (during the course of the 1990s decade). In contrast, the remaining two-thirds of the developing world, with a large concentration in Africa, that did not experience trade expansion due to a lack of sufficient outward orientation, performed poorly both in terms of growth and poverty reduction. Other studies look at the relationship between openness and growth, the presumption being growth is good for the poor. Thus, Wacziarg (1998) investigates the links between trade policy and economic growth using data from a panel of 57 countries from 1979-89. The results suggest that trade openness has a strong positive impact on economic growth. Similarly, Frankel and Romer (1999) using cross-country regressions conclude that trade has a quantitatively large, significant and robust positive effect on income. Dollar (1992) examines sources of growth in 95 developing countries during 1976-85 and finds a strong positive correlation between a measure of outward orientation and per capita GDP growth. Bhagwati and Srinivasan (2001) point out that practically no country that has been close to autarky has managed to sustain a high growth performance over a long period. The above examples provide strong evidence that greater trade openness is good for growth and poverty reduction over the longer term. It also suggests that there may be short term costs in terms of falling real wages of unskilled labour and or initially declining employment as greater competition drives out inefficient firms from business. Although these transition costs do not represent a credible case against trade openness, as the longer-term benefit would invariably offset these short-term costs, they need to be tackled through proper compensatory policies aimed at mitigating such costs.

\subsection{Phases of Trade Liberalization in Bangladesh}

Trade liberalization policies pursued by Bangladesh have passed through three phases. The first phase (1982-86) was undertaken as Bangladesh came under the purview of the policy based lending of the World Bank; the second phase (1987-91) began with the initiation of the three year IMF structural adjustment facility (SAF) in 1986; and finally, the third phase since 1992, was preceded by the IMF sponsored Enhanced Structural Adjustment Facility (ESAF) (BIDS, 2003). These reform measures led to a significant decline in quantitative restrictions, opening up of trade in many restricted items, rationalization and diminution of import tariffs, and liberalization of foreign exchange regime. 
Table 1. Changes in economic indicators for liberalization

\begin{tabular}{|c|c|c|c|c|c|c|c|}
\hline \multirow{2}{*}{$\begin{array}{l}\text { Economic Indicators } \\
\text { (In million US\$) }\end{array}$} & \multicolumn{3}{|c|}{ Pre-Liberalization Period } & \multicolumn{4}{|c|}{ Post-Liberalization Period } \\
\hline & 1976-80 & 1981-85 & 1986-90 & 1991-95 & 1996-00 & 2001-05 & 2006-10 \\
\hline GDP per capita & 154.2 & 196.8 & 230 & 271.8 & 324 & 354.6 & 504 \\
\hline GDP at constant price & 19,164 & 22,789 & 27,321 & 33,472 & 42,515 & 55,054 & 71,837 \\
\hline GDP Growth Rate (\%) & 4.4 & 4 & 4 & 4.4 & 5.2 & 5.2 & 6.2 \\
\hline Total population & 85.6 & 97.8 & 110.8 & 123.2 & 135.8 & 148.2 & 160 \\
\hline Investment & 1,747 & 3,040 & 4,264 & 5,686 & 9,155 & 13,615 & 20,089 \\
\hline Inflation (\% change in CPI) & --- & 11.57 & 7.84 & 5.6 & 5 & 5.4 & 7.7 \\
\hline Trade \% of GDP & 18.4 & 16.4 & 18.4 & 22.6 & 31.4 & 36 & 45.2 \\
\hline Total Export & 941.4 & 1,381 & 1,721 & 2,914 & 5,460 & 8,410 & 15,018 \\
\hline Total Import & 2,191 & 3,321 & 3,845 & 4,783 & 8,166 & 10,383 & 17,435 \\
\hline Remittances & 144.6 & 510 & 725 & 1,008 & 1,645 & 3,199 & 8,481 \\
\hline Current Account Balance & -411.8 & -499 & -526.6 & -3.8 & -396.4 & -23.8 & 1319 \\
\hline FDI inflow & 4.2 & 1 & 2.5 & 6 & 161 & 332 & 623 \\
\hline Real Exchange Rate & ---- & 45 & 48 & 53 & 54 & 63 & 63 \\
\hline Real Interest Rate & 6.4 & 1 & 7 & 10.4 & 10 & 11 & 8.2 \\
\hline
\end{tabular}

Source: WDI, 2010

The economic indicator in table 1 clearly shows GDP per capita has been increasing since pre liberalization period and continuing to move at a faster rate up to now. Besides, FDI and remittances show high growth rate in the post liberalization period. Both exports and imports have increased noticeably since liberalization, with imports rising faster than exports in the period immediately after liberalization.

However, the inflation rate fell with liberalization, possibly due to availability of cheaper imported goods, and demand management conditionality of the international financial institutions. Yet, by the period 2006-2010, the inflation rate had returned to its pre-liberalization levels. The growth rate of GDP in the post-liberalization period was significantly higher. The availability of imported intermediate and investment goods was a factor in the growth. The post-liberalization period showed a huge jump in FDI. These and other contributory factors lead to a higher GDP growth trajectory after liberalization.

\section{Methodology}

In previous section we have analyzed the impact of trade liberalization on growth descriptively for the developing countries and Bangladesh. In the subsequent section we model the effect of trade liberalization (in other words trade openness which is measured by export plus import divided by GDP) on growth, exports, imports and inflation for particularly Bangladesh Economy. We apply Ordinary Least Square (OLS) regression technique as the main methodology by using E- views 7 software and our data set comprises from 1980-2010. Most of the data are collected from World Development Indicators (WDI) 2010. We examine whether these models support the existing literatures of trade openness and growth.

\section{Results and Discussions}

\subsection{Openness and Growth}

The relationship between openness and growth is a contentious one empirically. While many writers have found a positive relationship, there are those who have found no relationship or even a negative relationship (see Rodriguez and Rodrik, 1999 for a comprehensive survey). We investigate the relationship between openness and growth initially in regression model. In the regression model, we regress GDP growth (gY) by openness (lnOPEN), the growth rate of capital $(\mathrm{gK})$, the growth rate of the labor force $(\mathrm{gL})$ and a dummy variable for natural disasters (DND). In Bangladesh, the economy is often adversely affected by floods and cyclones which affect output, especially agricultural output.

In estimating the regression, it became evident that the openness variable was endogenous. Hence, instrumental variable methods were used. Initially, we used foreign direct investment as a percent of GDP as the instrument. The correlation between these two variables was around 0.7 which is satisfactory for an instrument. Then, 
openness was regressed by foreign direct investment. The fitted values of openness were used as the instrument. The fitted values and actual values of openness were strongly correlated at 0.8 .

The estimated regression is:

$$
\begin{array}{ccccc}
\mathrm{gY}=-0.0029+0.0117(\operatorname{lnOPEN}) *-0.0371 \mathrm{gK}+1.2537 \mathrm{gL}-0.0076 \mathrm{DND} \\
(-0.6201) & (6.5854) & (-0.6219) & (3.3804) & (-3.1532) \\
R^{2}=0.7261, & \bar{R}^{2}=0.6439, & \mathrm{~F}=8.8, & \mathrm{D}-\mathrm{W}=2.04,
\end{array}
$$

Where, $(\operatorname{lnOPEN}) *$ is the instrument for $\operatorname{lnOPEN}$.

(t- Statistics are in parentheses)

The results confirm a positive and significant relationship between openness and growth. However, the effect of growth in capital on GDP growth turns out with a negative and statistically insignificant coefficient. This could either be due to errors in the capital stock series or capital also being endogenous. Since our primary interest is in the effect of openness, we did not pursue constructing an instrument for capital. The effect of the labour force growth is positive and significant. The natural disaster dummy is negative implying that such disasters affect growth adversely. The coefficient is statistically significant.

\subsection{Openness, Exports and Imports}

Openness is expected to affect exports and imports of goods and services. Imports are expected to raise as the country increases its demand for foreign goods and inputs. The import demand for intermediate and investment goods rises. Similarly, greater openness is expected to increase exports as the country gets integrated in the world market and begins to produce for it. In order to test the above, we formulated two equations. In the first, real exports (ZX) are a function of openness (OPEN), world income (Y*), the terms of trade (TOT) and the real exchange rate (RER). All variables are in logarithms. We would expect a positive sign on the coefficients of OPEN and $\mathrm{Y}^{*}$, but a negative sign on TOT as increases in the relative price of exports will reduce demand for exports. We would also expect a positive coefficient on RER because real depreciation would increase real export.

The estimated equation is:

$$
\operatorname{lnZX}=39.2309+0.7902 \operatorname{lnOPEN}-0.6480 \ln \mathrm{Y}^{*}-0.7306 \ln \mathrm{TOT}+0.7730 \ln R E R
$$

$$
\begin{aligned}
& \text { (3.1845) (8.8130) } \\
& \bar{R}^{2}=0.9921, \\
& (-1.15113) \\
& (-4.7704) \\
& \mathrm{D}-\mathrm{W}=1.27 \text {, }
\end{aligned}
$$

The openness variable is statistically significant at $1 \%$ level of significance and is of the expected sign. The TOT variable is also significant at $1 \%$ level and of the expected sign. However, the world income variable is statistically insignificant and has the wrong sign. It is unlikely that a small exporter of goods like Bangladesh will have its exports affected by world income changes. This probably explains why the coefficient on the $\mathrm{Y}^{*}$ variable is insignificant. The real exchange rate has the expected sign and is statistically significant.

For real imports (ZM), we assume that they are determined by openness (OPEN), domestic real income (Y), the terms of trade (TOT), and the real exchange rate (RER). The expectations are that openness and domestic real income will have positive coefficients, the terms of trade to have a positive coefficient and the real exchange rate to have a negative coefficient. The estimated regression is:

$$
\operatorname{lnZM}=20.7038+0.4742 \ln O P E N+0.3062 \ln Y-0.3371 \ln T O T-0.6995 \ln R E R
$$

$$
\begin{aligned}
& \text { (2.7829) } \\
& \text { (3.1717) } \\
& \text { (0.5579) } \\
& \text { (-1.0071) } \\
& (-1.3453) \\
& R^{2}=0.9704, \\
& \bar{R}^{2}=0.9655, \\
& \mathrm{D}-\mathrm{W}=1.63 \text {, } \\
& \mathrm{F}=196.90
\end{aligned}
$$

The regression confirms that when openness increases, real imports increase. The coefficient on the openness variable is both positive and statistically significant at $1 \%$ level. The coefficients on the real income variable of Bangladesh is positive as expected but not statistically significant. For a low income country like Bangladesh it is unlikely that increases in income lead to increase in imports. The terms of trade variable have an unexpected negative coefficient but it is statistically not significant. The real exchange rate variable has the correct sign but is statistically insignificant.

In summary, we see that both exports and imports increase with greater openness. This may seem obvious. However, greater openness can result from just an increase in imports (or exports) and therefore does not imply that both imports and exports increase. 


\subsection{Openness and Inflation}

As openness increases, the inflationary situation in a country could be reduced or increased. The higher imports to a country consequent to greater openness could reduce the price level in a country as the international price level is expected to be lower than domestic price level for a country like Bangladesh. On the other hand, increased imports could adversely affect the current account balance and consequently depreciate the value of the domestic currency. This could lead to inflation.

We assume that the inflation variable (YDEF) is the percentage change in the GDP deflator. It is dependent on the growth rate of real GDP (gY), the growth rate of the narrow money supply (gM1) and the logarithm of openness $(\operatorname{lnOPEN})$.

The estimated equation is:

$$
\begin{array}{cccc}
\multicolumn{5}{c}{\text { YDEF }=-21.2322-98.200 \mathrm{gY}+12.3494 \mathrm{gM} 1+6.1997 \operatorname{lnOPEN}} \\
(-0.7786) & (-1.9285) & (2.0451) & (1.3114) \\
R^{2}=0.5738, & \bar{R}^{2}=0.4997, & \mathrm{D}-\mathrm{W}=2.34, & \mathrm{~F}=7.74
\end{array}
$$

The openness variable is not statistically significant at conventional levels which mean that it possibly does not condition inflation in the country. Increases in output depress the price level, although it is not significant. The money supply exerts a positive and statistically significant (5\%) effect on inflation.

The quantitative analysis undertaken in this section suggests that greater openness has had a favourable effect on economic growth. Both real export and imports have increased with greater openness. This is to be expected anyway. Finally, the effect of greater openness on the inflation rate is inconclusive. These results support to a great extent the conclusions of the literature reviews in previous section. We believe that the econometric work in this section could have been improved by time series techniques. However, the small sample discouraged us from doing so.

\section{Conclusion}

The quantitative analysis undertaken in this study suggests that greater openness has a favourable effect on economic growth of Bangladesh. Both real export and imports have increased with greater openness. The effect of greater openness on the inflation rate is inconclusive. Hence, we conclude that liberalization policy certainly improves export of the country which eventually leads higher economic growth after 1990s. The volume of international capital, the magnitude of capital formation, balance between import and export growth and FDI in general, being the robust determinants of economic growth, it is expected that the government of Bangladesh should provide more emphasis of the above factors to increase its economic growth. Side by side, the government should formulate export led fiscal and monetary policies to increase its exports as well as rates of GDP growth. Hence, with the empirical evidence and policy suggestions the study tries to reveal the overall effect of trade liberalization on economic growth of Bangladesh. Finally, we believe this research can be a positive contribution of trade liberalization policy study in developing countries.

\section{References}

Ahmed, S., \& Sattar, Z. (2004). Trade liberalization, growth and poverty reduction: the case of Bangladesh. Discussion paper-34204.

Bangladesh Institute of Development Studies (BIDS) and Federation of Bangladesh Chambers of Commerce and Industry (FBCCI). (2003). Recent performance of the Bangladesh economy: An assessment of the state of the economy and short-term outlook. (Seminar Paper). Dhaka.

Bhagwati, J., \& Srinivasan, T. N. (2001). Trade and poverty in the poor countries. American Economic Review, 92(2), 180-183. http://dx.doi.org/10.1257/000282802320189212

Dollar, D. (1992). Outward-oriented development economies really do grow more rapidly: Evidence from 95 LDCs, 1976-1985. Economic Development and Cultural Change, 40(3), 523-544. http://dx.doi.org/10.1086/451959

Dollar, David, \& Kraay, A. (2001). Trade, growth, and poverty. World Bank, Development Research Group, Washington, D.C.

Frankel, J. A., \& Romer, D. (1999). Does trade cause growth? The American Economic Review, 89(3), 379-399. http://dx.doi.org/10.1257/aer.89.3.379

Islam, S. (2001). The textile and clothing industry of Bangladesh in a changing world economy. Dhaka: Centre 
for Policy Dialogue and the University Press Limited

Krugman, P. R. (1990). Rethinking International Trade. Massachusetts: The MIT press

McCulloch, N., Alan, L., Winters, \& Cirera, X. (2001). Trade Liberalization and Poverty: A Handbook. UK Department for International Development and the Centre for Economic Policy Research, London.

Rodriguez, F., \& Rodrik, D. (1999). Trade policy and economic growth: A skeptic's guide to cross-national evidence. National Bureau of Economic Research, Inc Working Papers-7081.

Rodrik, D. (1996). Understanding economic policy reform. Journal of Economic Literature, 34, 9-41.

Rodrik, D. (1997). Has globalization gone too far? Institute for International Economics, Washington D.C.

World Bank. (2010). World Development Indicator and Global Development Finance 2010. Washington, DC: World Bank. 